Современная Европа, 2020, №2, с. 20-32

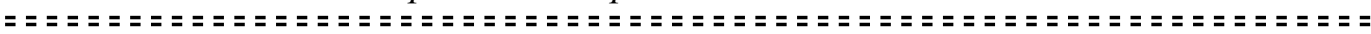

УДК 339.92321 .8

Ольга БУТОРИНА

\title{
СУЖЕНИЕ ЕВРОПЕЙСКОГО СОЮЗА И ПОТЕНЦИАЛ ИНТЕГРАЦИИ
}

\begin{abstract}
Алиса уже почти догнала его, вслед за ним повернув за угол, но Кролика больше не было видно...

Л. Кэррол, “Алиса в стране чудес"
\end{abstract}

\begin{abstract}
Аннотация. 31 января 2020 г. из Евросоюза вышла Великобритания, страна с населением 67 млн человек и пятая экономика мира. Случай, когда государство перестало быть членом ЕС - первый в истории европейской интеграции. Если не считать эпизода с Гренландией, покинувшей ЕЭС в 1985 г., до этого группировка неизменно расширялась. Существующий на сегодня обширный свод научной литературы о брекзите представлен преимущественно работами, объектом которых является Великобритания. Меньше работ посвящено Евросоюзу, а в них в основном рассматриваются институциональные вопросы, такие как соотношение наднациональных и межправительственных методов управления, плюсы и минусы дифференцированной интеграции. Данная статья ставит проблему более широко. Её цель - прояснить, каким образом брекзит скажется на стратегическом потенциале интеграции, а не на её формах. Автор приходит к выводу, что, хотя ЕС несёт существенные экономические, политические и смысловые потери, выход Великобритании парадоксальным образом сообщает динамизм интеграционному процессу. Возникают предпосылки для формирования в Европе двух конкурирующих демократических режимов. Новая ситуация подводит черту под длившимся 30 лет (с падения Берлинской стены) периодом идейного и институционального доминирования ЕС как безальтернативной модели европейского развития. Соперничество с Великобританией может быть крайне полезно ЕС для переосмысления своих установок, отказа от догм и выработки новой идеологии интеграции, которая отвечала бы уже не условиям биполярного противостояния, а вызовам зрелой глобализации.

Ключевые слова: Европейский союз, Великобритания, брекзит, региональная интеграция, дезинтеграция.
\end{abstract}

31 января 2020 г. Великобритания официально перестала быть членом Европейского союза. Эксперты называют это событие политическим землетрясением, одним из худших кризисов в истории интеграции и свидетельством её тяжёлой болезни [Кавешников, 2016: 25; Rodríguez Suárez, 2020:163; Вершинин, 2017: 83].

С лета 2016 г., когда проводившийся в Великобритании референдум о членстве в ЕС принёс негативный результат, на тему брекзита был создан значительный массив литературы. Он даёт всестороннее представление о мотивах принятого бри-

(C) Буторина Ольга Витальевна - чЛ.-корр. РАН, доктор экономических наук, профессор, заместитель директора Института Европы РАН. Адрес: 125009, Россия, Москва, ул. Моховая, 11-3. E-mail: butorina@ieras.ru

DOI: http://dx.doi.org/10.15211/soveurope220202032 
танцами решения, о проблемах его реализации и о перспективах страны вне союза [Ананьева, 2018; Бабынина, 2019а; Кавешников, 2018а и 2018б; Худолей, Ерёмина, 2017; Murray, Brainson, 2019; Bickerton, 2019; Felbermayr, 2019; Pelkmans, 2019]. Меньше внимания уделялось вопросу о том, как это событие скажется на Евросоюзе, а главное - какими могут быть долгосрочные последствия для интеграционного процесса [Бабынина, 2019б и 2019с; Байков, Дымова, 2017; Громыко, 2017; Юд, 2017; Leruth, Gänzle, Trondal, 2019a and 2019b].

С уходом Великобритании Евросоюз лишился, по крайней мере, трёх символов, игравших важную роль в его самопрезентации. Во-первых, он больше не может именовать себя “общим домом” для полумиллиарда человек или рынком с 500 миллионами потребителей. Население группировки сократилась на 67 млн человек, что не оставляет шансов вернуться к прежней представительной отметке. Все шесть стран, ожидающих в настоящее время приема в Евросоюз (Албания, Босния и Герцеговина, Косово, Черногория, Северная Македония и Сербия), невелики по размерам, а их совокупное население не превышает 18 млн человек.

Во-вторых, привычное для официального Брюсселя отождествление Европы с собой, а, по сути, присвоение себе права говорить от имени всех европейских народов, теперь теряет основания. За пределами Евросоюза остаются не только Россия, Украина, Белоруссия, Швейцария, Норвегия, Исландия и другие страны, без которых немыслима современная европейская культура. К когорте “аутсайдеров” подключается Великобритания, которая сыграла огромную роль в процессе формирования теории и практики представительной демократии. Вступив вслед за Нидерландами на путь индустриализации, Великобритания в последней трети XVIII в. стала ведущей промышленной державой мира. Выдающийся вклад Великобритании в мировую культуру не позволяет вывести страну за пределы ежедневной жизни и менталитета современных европейцев.

В-третьих, брекзит нанёс удар по авторитету Евросоюза. Идея органичного сочетания двух процессов - углубления и расширения интеграции, больше не соответствует реальности. Лозунг о высокой привлекательности ЕС для соседних стран, который официальный Брюссель взял на вооружение после распада социалистической системы, утрачивает убедительность. Раз желанию отдельных стран вступить в ЕС нашелся антипод, он уже не годится для подтверждения исторической правоты Евросоюза и обоснованности его нынешнего курса.

\section{Экономическое измерение брекзита}

Вопреки распространенному мнению, самым крупным в истории европейской интеграции было западное пополнение 1973 г. (когда к шести странам ЕЭС присоединились Великобритания, Ирландия и Дания), а вовсе не восточное расширение 2004-2007 гг., когда в Евросоюз вошли 10 государств Центральной и Восточной Европы, Кипр и Мальта. В первом случае население группировки увеличилось на $31 \%$, а ВВП - на 27\%. Во втором случае население увеличилось на $27 \%$, а ВВП только на $6 \%$, поскольку бывшие социалистические страны имели сравнительно невысокий уровень жизни ${ }^{1}$.

\footnotetext{
${ }^{1}$ Расчёты сделаны по электронной базе данных UNCTADStat.
} 
После выхода Великобритании население Евросоюза уменьшилось на 13\%. Понесенный демографический урон равнозначен выбытию из объединения всех государств восточного расширения 2004-2013 гг., кроме Польши ${ }^{1}$. При этом совокупный ВВП Евросоюза сокращается на 2,5 трлн евро, или на 15\%. Поскольку Великобритания относится к числу относительно богатых стран, после брекзита средний для Евросоюза ВВП на душу населения понизился на 650 евро (Табл. 1).

Таблица 1.

Некоторые макроэкономические последствия брекзита

\begin{tabular}{|c|c|c|c|c|c|c|}
\hline & Показатель & $\begin{array}{l}\text { Единица из- } \\
\text { мерения }\end{array}$ & EC-28 & $\begin{array}{l}\text { Велико- } \\
\text { британия }\end{array}$ & $\mathrm{EC}-27$ & $\begin{array}{l}\text { EC-27/ } \\
\text { EC-28 }\end{array}$ \\
\hline 1 & Население & Млн человек & 513,5 & 66,6 & 446,8 & 0,87 \\
\hline 2 & ВВП & Млрд евро & 15907 & 2423 & 13484 & 0,85 \\
\hline 3 & $\begin{array}{l}\text { ВВП на душу населения в це- } \\
\text { нах } 2010 \text { г. }\end{array}$ & евро & 28630 & 32960 & 27980 & 0,98 \\
\hline 4 & Расходы на НИОКР & Млрд евро & 336 & 41 & 295 & 0,88 \\
\hline 5 & Товарный экспорт & Млрд долл. & 6468 & 487 & 5981 & 0,92 \\
\hline 6 & $\begin{array}{l}\text { Доля ЕС в мировом товарном } \\
\text { экспорте }\end{array}$ & $\%$ & 33,2 & 2,5 & 30,7 & - \\
\hline 7 & Экспорт цифровых услуг* & Млрд долл. & 1449 & 266 & 1183 & 0,82 \\
\hline 8 & Экспорт ИКТ услуг & Млрд долл. & 307 & 23 & 284 & 0,93 \\
\hline
\end{tabular}

Источники: пункты 1-4 - Евростат; остальные пункты - UNCTADStat.

Примечания. Данные по населению, душевому ВВП и безработице - 2019 г., остальные 2018 г. Данные по товарному экспорту включают торговлю между странами ЕС.

* По методологии ЮНКТАД - digitally-deliverable services.

Великобритания знаменита своей либеральной экономической моделью. По доле ВВП, перераспределяемого через государственные бюджеты всех уровней, она находится на одном уровне с Польшей и Чехией, пропуская вперёд Францию и большинство западноевропейских стран (Рис. 1). Следует ожидать, что уход Великобритании облегчит Евросоюзу прощание с рыночным фундаментализмом и поиск нового, соответствующего условиям глобальной цифровой экономики, баланса между общественным благом и индивидуальной свободой. Усилению функций государства будет способствовать сразу несколько факторов: снижение эффективности денежно-кредитной политики, а также усиление роли фискальной, структурной и пруденциальной политики [Хесин, 2020]. В марте 2020 г. в связи с пандемией коронавируса Европейская комиссия впервые за последние 30 лет расширила возможности государств-членов оказывать помощь предприятиям, в том числе путём частичной

${ }^{1}$ Всего двенадцать стран: Болгария, Венгрия, Кипр, Латвия, Литва, Мальта, Румыния, Словакия, Словения, Хорватия, Чехия, Эстония. 
национализации [European Commission, 2020b]. Одновременно было приостановлено действие Пакта стабильности и роста, с тем чтобы правительства могли влить дополнительные денежные средства в экономику [European Commission, 2020b].

Рисунок 1.

Отношение общих расходов государства к ВВП в 2018 г., \%

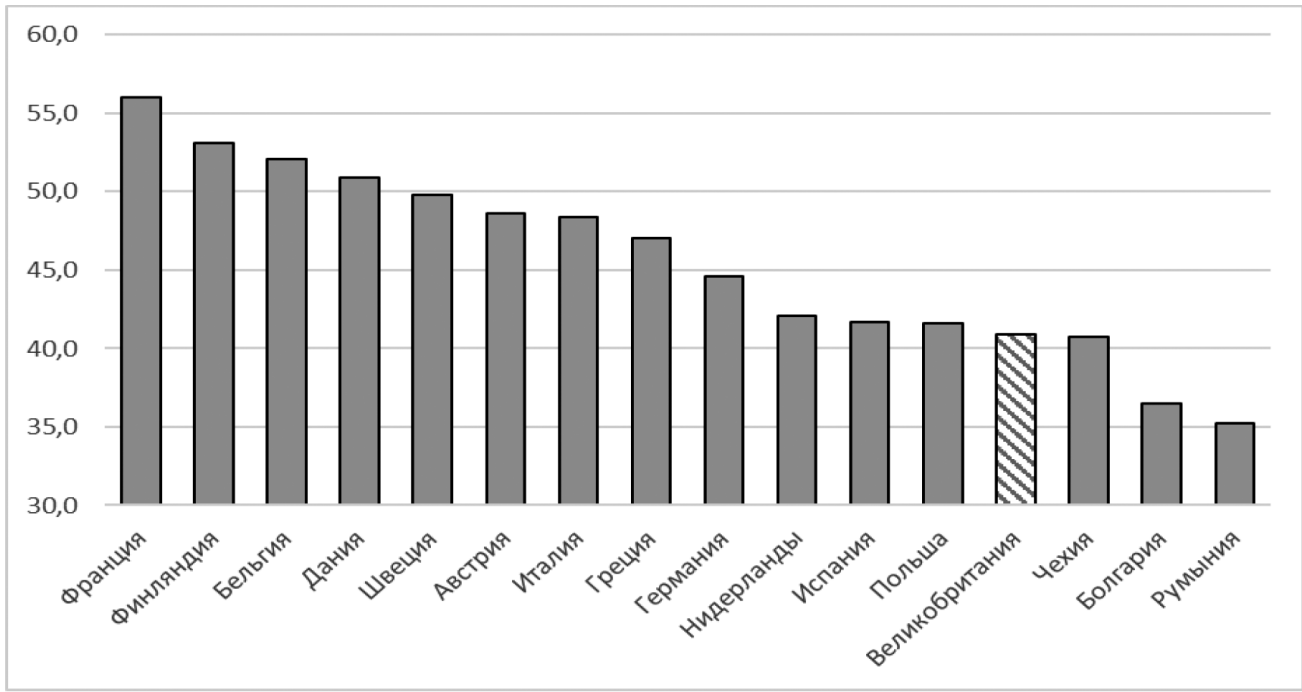

Источник: Евростат.

Брекзит умеренно повлиял на позиции Евросоюза в мировой торговле. Доля объединения в мировом товарном экспорте снизилась на 2,5 процентных пункта. Примерно на 7\% уменьшилась стоимость информационно-телекоммуникационных услуг, которые страны ЕС оказывают зарубежным партнёрам. Заметная убыль наблюдается в сфере международной торговли цифровыми услугами. Их общий рынок оценивался в 2018 г. в сумму 2,9 трлн долл., из которых 1,4 трлн долл., давали страны ЕС-28. Наибольший вклад (266 млрд долл.) вносила именно Великобритания. За ней с заметным отрывом следовали Германия, Ирландия, Нидерланды и Франция с показателями в диапазоне 150 - 190 млрд долл. После брекзита доля ЕС на данном глобальном рынке сократилась с 49\% до 40\% (Табл. 1).

Великобритания всегда играла важную роль на международных рынках капитала, будучи до 2008 г. крупным нетто-экспортером прямых иностранных инвестиций (ПИИ). На конец 2018 г. на неё приходилось 5,9\% мирового запаса входящих и 5,5\% исходящих ПИИ. Те же показатели для ЕС-28 равнялись 31,3\% и 37,1\% соответственно ${ }^{1}$. Иными словами, вследствие брекзита Евросоюз лишается примерно пятой части своего прежнего сегмента на глобальном рынке прямых зарубежных капиталовложений. Совокупные активы британских банков оценивались на конец сентября 2019 г. в сумму, равную 7,4 трлн долл., что составляло почти 9\% от соответствующей мировой величины - 86,5 трлн долл. Тогда же банковские активы

\footnotetext{
${ }^{1}$ Расчёты сделаны по электронной базе данных UNCTADStat.
} 
Франции оценивались в 8,2 трлн долл., а Германии - 8,1 трлн долл. ${ }^{1}$ То есть показатель Великобритании являлся весьма внушительным, но не рекордным для Евросоюза. Зато Великобритания явно обгоняла партнёров в сфере производных финансовых инструментов. Так, в декабре 2019 г. в фунтах стерлингов было номинировано биржевых процентных фьючерсов и опционов на сумму свыше 9 трлн долл., что равнялось 9\% их общемирового объёма. Доля евро на соответствующих рынках не превышала 15\%, тогда как 70\% подобных сделок заключалось в долларах США 2 .

Высокоразвитая банковская и финансовая инфраструктура Сити делала его удобным хабом для операторов из стран ЕС и отчасти снижала их заинтересованность в создании таких сервисов на собственной территории. Показательный пример: в декабре 2019 г. почти 90\% внебиржевых расчётов по деривативам для клиентов из зоны евро совершались клиринговыми палатами Великобритании. В 20122018 гг. почти половина акций и долговых ценных бумаг нефинансовых учреждений стран еврозоны эмитировались международными банками, базирующимися в Лондоне. Выход Великобритании из ЕС повышает, по мнению Европейского центрального банка, риск фрагментации финансового пространства еврозоны, а также создает почву для опасной “гонки до дна" в сфере регулирования банковской деятельности и рынков капитала [de Guindos, 2020].

В 2019 г. на фунт стерлингов приходилось 13\% оборота мировых валютных рынков, тогда как доля евро составила $32 \%$, а американского доллара $-88 \%{ }^{3}$ (напомним, что общий итог по данному показателю всегда равен 200\%, так как в каждой валютной сделке участвуют две денежные единицы). Поскольку Великобритания не входила в зону евро, данный факт едва ли следует расценивать как потерю от брекзита. Слабая надежда на присоединение Великобритании к единой валюте растаяла после мирового экономического кризиса, когда Евросоюз начал решительно достраивать здание Экономического и валютного союза, никак не считаясь с интересами Сити [Буторина, 2013: 76].

Гораздо менее известен и потенциально опасен другой факт: Лондон традиционно является главной мировой площадкой торговли валютами. А размер этого рынка поистине грандиозен. В апреле 2019 г. дневной оборот мировых валютных рынков достиг 8,3 трлн долл. (что эквивалентно почти 10\% годового ВВП всего мира). При этом в одной только Великобритании совершалось сделок на сумму 3,6 трлн долл., что составляло 43\% (!) мирового оборота. Соответствующая доля Соединённых Штатов была почти втрое меньше - 16\%. Позиции ведущих государств EC-27 не шли ни в какое сравнение с ролью Сити. На Францию приходилось 2,0\% оборота мировых валютных рынков, на Германию - 1,5\%, на Нидерланды - 0,8\%, на Испанию - 0,5\%, а на Италию - 0,2\% ${ }^{4}$. Таким образом, после брекзита государства $\mathrm{EC}$, включая еврозону, попадают в зависимость от норм и практик регулирования валютных сделок в стране, на которую теперь не распространяется право Евросоюза.

\footnotetext{
${ }^{1}$ Данные Банка международных расчётов в Базеле. Summary of consolidated statistics, by nationality of reporting bank. Stocks at end-September 2019.

2 Данные Банка международных расчётов в Базеле. Exchange-traded futures and options, by currency Notional principal.

3 Данные Банка международных расчётов в Базеле https://stats.bis.org/statx/srs/table/d11.3

${ }^{4}$ Данные Банка международных расчётов в Базеле https://stats.bis.org/statx/srs/table/d11.2
} 


\section{Политические и смысловые потери}

Для того, чтобы понять, чего Евросоюз лишается в плане возможностей и авторитета интеграции, полезно обратиться к документам той поры, когда Великобритания пополняла ряды участников Сообщества. Уже на стадии переговоров было ясно, что её вступление не будет простым актом географического расширения. "Шестёрка" приобретала ценные политические активы, ощутимо повышала свой вес в международных делах. Об этом красноречиво свидетельствуют материалы первой встречи глав государств и правительств ЕЭС, организованной по инициативе двух лидеров Франции и Германии - Жоржа Помпиду и Вилли Брандта. Поскольку в 1968 г. Сообщества выполнили план создания таможенного союза, настало время определить дальнейшие стратегические направления интеграции. На очереди стоял вопрос о формировании собственных ресурсов Сообществ и валютного союза.

Саммит открылся 1 декабря 1969 г. в Гааге. На второй день в залы заседаний пригласили представителей Комиссии ЕЭС. В итоговом коммюнике саммита сообщалось, что "Европейские сообщества остаются изначальным ядром, из которого возникло и развилось европейское единство". Вступление новых стран, “безусловно, поможет Сообществу вырасти до размеров, ещё более соответствующих современному уровню развития экономики и технологий" [The "Summit Conference", 1969, point 4]. Комиссия называла предстоящее расширение "существенным фактором в создании Европы”, призывала к скорейшему началу переговоров со странами-кандидатами и подтверждала свою установку на параллельное укрепление и расширение Сообщества [European Commission, 1969: 3-4].

Первое расширение рассматривалось лидерами ЕЭС как шанс изменить расстановку сил в условиях биполярного противостояния, когда повестку дня определяли две сверхдержавы - США и Советский Союз. Теперь, по словам Ж. Помпиду, у Западной Европы появлялся шанс "вернуть средства влияния" и заявить о себе в полный голос "во всех сферах мировой политики" [Pompidou, 1969]. Предельно ясно высказался В. Брандт: “Сообщество должно выйти за пределы “шестёрки”, если оно хочет экономически и технологически противостоять сверхдержавам и выполнять свои обязательства по всему миру”. И далее: “в любом случае... без Великобритании и других стран, которые подали заявки на членство, Европа не может стать тем, чем должна и может быть" [Brandt, 1969]. Именно с Гаагского саммита страны ЕЭС начали именовать себя Европой. До этого в официальных документах использовались названия "ЕЭС”, “Сообщества" и "шестёрка”. Знак равенства между Европой (а под ней подразумевалась Западная, то есть “демократическая” Европа, в противовес “недемократической” Восточной Европе) и ЕЭС никогда не ставился. Смысловая экспансия стала возможной благодаря присоединению большой и высокоразвитой Великобритании, которая одновременно покидала созданную ею же конкурирующую группировку - Европейскую ассоциацию свободной торговли.

Членство Великобритании, традиционного и близкого партнёра США, придавало Сообществу дополнительный политический вес. Великобритания, Ирландия и Дания, напомним, вступили в ЕС 1 января 1973 г., а 24 апреля госсекретарь США Г. Киссинджер призвал партнёров заключить "Новую Атлантическую хартию”. Соединённым Штатам предстояло выполнять функции политического лидера всего Запада, а Западной Европе - играть второстепенную, подчиненную роль. Официальный 
Брюссель встал на дыбы. Комиссия недвусмысленно осудила мессианские притязания Вашингтона. “Девятка” отстояла право на внешнеполитическую идентичность, что было бы крайне трудно или невозможно сделать без поддержки Лондона.

Согласно официальной позиции, после выхода из ЕС Великобритания намерена играть роль глобальной державы, хотя, по мнению экспертов, она останется в категории “средней державы” [Murray, Brainson, 2019]. Как бы там ни было, Евросоюз более не сможет использовать британский ресурс в своей внешней политике. На Великобританию перестают распространяться принципы Общей внешней политики и политики безопасности. Очевидно Великобритания будет проводить собственную линию в отношении регионов, с которыми она связана историческими узами и стратегическими интересами, такими как Китай, Индия, Ближний Восток.

Вероятны подвижки в рамочном диалоге ЕС со странами Африки, Карибского бассейна и Тихоокеанского региона. Некоторые из них прежде были зависимыми территориями Великобритании, в том числе: Ботсвана, Гамбия, Гана, Гайана, Кения, Лесото, Малави, Нигерия и Судан с общим населением 350 млн человек. Все они подключились к системе преференциальных соглашений с ЕЭС после того, как в Великобритания вошла в Сообщество. Срок ныне действующего между сторонами Договора Котону истекает в декабре 2020 г. Захотят ли страны EC-27 и дальше оказывать помощь “чужим” беднейшим государства, где они будут сталкиваться с интересами Великобритании и её компаний - большой вопрос.

Брекзит ещё больше затрудняет определение европейской идентичности и ментальных границ Европы. Для обычного человека совершенно очевиден исключительный вклад Великобритании в мировую культуру и, прежде всего в литературу. Многие образы, созданные Шекспиром и его соотечественниками от Джонатана Свифта до Бернарда Шоу, прочно вошли не только в европейский менталитет, но и в ежедневный речевой обиход, стали неотъемлемой частью политического дискурса. Теперь же любые упоминания о Гамлете или Шерлоке, привычные аллюзии на "Робинзона Крузо”, “Гулливера", “Алису в стране чудес" или "Пигмалиона” - станут политически чувствительными. Перед спикерами ЕС возникнет неприятная альтернатива: либо аккуратно вырезать из своих выступлений всех Оливеров Твистов и Белых Кроликов (как некоторые разведенные супруги удаляют из семейного альбома фотографии своих “бывших”) - либо делать вид, что ничего не случилось, что Скрудж и Маугли остаются старинными гражданами Евросоюза. Но и в том, и в другом случае любой образованный европеец будет ощущать разницу между сузившимся в январе 2020 г. культурным пространством Европы - и претензией ЕС на то, чтобы быть распорядителем всей европейской мега-культуры.

Нетривиальная ситуация возникает вокруг английского языка. Как известно, первоначально официальные документы ЕЭС составлялись по-французски. Вступление в 1973 г. Великобритании и Ирландии мало повлияло на ситуацию. Английскому языку потребовалось не одно десятилетие, чтобы проникнуть в речевые практики европейских чиновников. Например, до конца 1987 г. протоколы заседаний Комитета управляющих центральными банками стран ЕЭС публиковались пофранцузски и по-немецки. На английский переводили только повестку дня заседаний. Английский сделался lingua franca европейской интеграции в 1990-е годы под давлением глобализации и расширения ЕС. 
После брекзита в объединении остается две страны, где английский язык является официальным - Ирландия и Мальта с общим населением 5 млн человек. Среди взрослого населения Евросоюза английский является самым распространенным иностранным языком, на нём могут вести беседу 38\% людей. Французским и немецким как иностранным владеет по 11-12\% взрослых. При этом почти половина граждан Евросоюза (46\%) не говорит ни на одном другом языке, кроме родного [European Commission, 2012: 7-11]. Органам Евросоюза придётся и дальше использовать английский в качестве языка международного общения, тогда как он не является родным для 99\% граждан. Лучшим выходом был бы перевод материалов на все 24 официальных языка, включая такие редкие как эстонский или хорватский. Но это потребует колоссальных сил и средств, размеры которых выходят за пределы разумного. Другой вариант - использование французского и немецкого языков в качестве частичной замены английскому - привёл бы Евросоюз к ситуации Вавилонской башни.

Выход Великобритании пресекает однозначную до сей поры тенденцию географического расширения европейской интеграции. После эмоционально окрашенного восточного расширения Евросоюза современники наблюдают его западное сужение. Если негативный исход британского референдума дал повод говорить о крахе "идеологии постоянного и неуклонного развития интеграции" [Кавешников, 2016: 24], то состоявшийся брекзит снял табу с рассмотрения европейской интеграции сквозь призму стандартных законов логики. Практическое подтверждение получил выдвинутый ранее тезис о циклическом, неравномерном ходе интеграционного процесса, когда "приливы" сменяются "отливами" [Байков, 2012: 30-31]. Раньше подобный цикл виделся как смена периодов роста и застоя, теперь же под низшей точкой понимается не торможение, а регресс. Недаром специалисты заговорили о гипотетической деконструкции Евросоюза, а в политический лексикон вернулось слово “дезинтеграция”.

\section{Потенциал интеграции}

Успешное становление Экономического и валютного союза и распространение ЕС на бо́льшую часть Европы создало в середине 2000-х гг. впечатление, что программа интеграции близка к выполнению. Согласно известной схеме Б. Балаши, после создания общего рынка и валютного союза объединению остаётся один шаг до политического союза. Мечта о Соединённых штатах Европы, построенных на принципах демократии и рыночной конкуренции, почти сбылась. Вопреки укоренившимся идеологическим установкам, валютный союз не стал "ракетойносителем" политического союза [Буторина, 2020: 523]. В тот момент, когда Евросоюз, как казалось, добился всего и мог праздновать историческую победу над поверженной плановой экономикой, большая цель ускользнула из виду - почти как Белый Кролик, за которым гналась Алиса в известной истории Льюиса Кэррола.

Случившийся в 2005 г. провал конституционного договора вызвал в ЕС глубокий политический и идейный кризис. Официальный Брюссель ещё много лет не мог признаться себе в утрате стратегической цели. В 2010 г. он попытался реанимировать неудавшуюся Лиссабонскую стратегию, выдвинув вместо неё стратегию "Европа 2020”. Под новым названием скрывалась всё та же бесплодная идея - соорудить из разрозненных интеграционных элементов привлекательный для общества конгломе- 
рат, не снабдив его идейным стержнем. Общественную мысль, как ни странно, не всколыхнул даже тяжелейший кризис зоны евро, поставивший её на грань распада. Складывалось впечатление, что дальнейшая судьба Евросоюза никого не интересует, а общество ждёт, когда решение придёт само откуда-то со стороны [Буторина, 2011: 192].

Подвижки наметились после майских выборов 2014 г. в Европейский парламент. Тогда председатель Европейского совета Херман Ван Ромпёй пригласил лидеров стран ЕС “обменяться мнениями о стратегической повестке дня Союза в эпоху перемен” [Van Rompuy, 2014]. Дискуссия ширилась по мере обострения миграционного кризиса и приближения британского референдума. 3 июня 2015 г. министры экономики Франции и Германии заявили о необходимости укрепления еврозоны путём проведения крупной реформы Евросоюза [Андреева, 2016: 117]. К глубокой реформе ЕС и упрощению его процедур публично призвали 14 декабря 2015 г. министры иностранных дел Великобритании и Италии.

Окончательное пробуждение наступило 24 июня 2016 г. в семь часов утра по лондонскому времени, когда стало ясно, что сторонники брекзита одержали победу. Уже через несколько дней главы государств и правительств, собравшиеся на неофициальную встречу 27-29 июня в Брюсселе, объявили о решении начать широкий обмен мнениями о путях интеграции. В январе 2017 г. председатель Европейского совета Дональд Туск разослал письмо лидерам государств-членов, где он назвал тогдашнее состояние умов одной из трёх главных угроз Европейского союза [Tusk, 2017]. Вскоре в свет вышла Белая книга о будущем Евросоюза [European Commission, 2017]. Новая Европейская комиссия под руководством Урсулы фон дер Ляйен представила публике обновлённый набор стратегических приоритетов ЕС, включая цифровизацию и “Зелёную сделку” [von der Leyen, 2019].

Итак, первая заслуга брекзита - выведение европейских элит из состояния идейного конформизма и бездействия.

Есть и другие аспекты. Уход Великобритании снижает эффективность широко применяемого органами ЕС принципа обусловленности. Его взяли на вооружение в начале 1990-х гг., когда сначала появились маастрихтские, а вскоре копенгагенские критерии (соответственно для стран, желавших вступить в валютный союз и в ЕС). Политическая сделка базировалась на имплицитном представлении, что попасть в закрытый клуб - большая удача. А раз туда стремятся все, значит “входной билет" надо заработать.

После того, как из клуба добровольно удалилась большая, довольно богатая страна, членство в нем перестает быть самоочевидной наградой. Прецедент переворачивает с ног на голову восприятие существующих внутри объединения созависимостей. Становится непонятно, кто кому больше нужен: Евросоюз той или иной стране или она ему. Как следствие, Евросоюз в лице его руководящих органов теряет монополию на истину. Его правила больше не могут считаться единственно верными, соответственно, сокращается его возможность выступать в качестве нормативной силы.

Подобный урон случился бы в результате выхода любой страны. Но случай Великобритании особенный. Теперь за пределами Евросоюза находится страна, которая в числе первых прокладывала дорогу к демократии и рыночным свободам. Англия XVIII столетия, как пишет Ларри Зидентоп, располагала намного большим опытом самоуправления, чем любое другое государство того времени. Её традиции 
парламентаризма и децентрализованного государства при чётко очерченных правах граждан и системе судебного контроля легли в основу политической культуры других народов [Зидентоп, 2001: 20].

У Германии, которая поневоле становится политическим и экономическим лидером Евросоюза, нет ни моральных, ни исторических оснований задавать стандарты “правильного поведения”. До вступления в ЕЭС Великобритании этой проблемы не существовало, так как деятельность Сообщества была сосредоточена вокруг экономических вопросов и не выходила за пределы таможенного союза. Когда же после крушения биполярной системы Брюссель выдвинул концепцию европейских ценностей в собственной интерпретации, они воспринимались таковыми постольку, поскольку членами ЕС являлись все ведущие государства Старого Света.

Больше этого охвата не существует. Между взглядами ЕС и Великобритании на то, к примеру, как должны работать независимые суды или защищаться права меньшинств, неминуемо возникнут зазоры. Представление о некоей общей норме Евросоюза будет расплываться. Под огонь критики вполне могут попасть нынешние прописные истины. До сих пор, например, не удалось эмпирически подтвердить, что соблюдение маастрихтских критериев, содействует экономическому росту и обеспечивает долговременную ценовую стабильность.

Конечно, Брюссель так просто не откажется от использования регулятивной силы. В недавно опубликованной стратегии цифрового будущего Евросоюз ставит задачу закреплять свои правила в соглашениях с третьими странами и в практике международных организаций, активно влиять на разрабатываемые глобальные стандарты передовых технологий [European Commission, 2020a]. Теперь Евросоюзу будет труднее задавать свои правила игры, поскольку с ним на одной площадке выступает Великобритания. Она, как уже было показано, имеет очевидные интересы в мировой торговле цифровыми услугами. Брюсселю предстоит не просто постулировать свои ценности и нормы, а обосновывать их.

Второе и самое важное следствие брекзита - размывание монополии на истину, которую Европейский союз присвоил себе после падения Берлинской стены.

\section{Заключение}

Выход Великобритании из Евросоюза заметно уменьшает его экономический и политический потенциал. Брекзит делает ещё более трудным вопрос о ментальных границах Европы и об идентичности европейцев. По всем законам логики, Евросоюз утрачивает право отождествлять себя с Европой и выступать от имени всего Старого Света, хотя он едва ли сам откажется от подобной практики.

EC несёт существенные репутационные потери и не только из-за того, что группировку покинула большая страна с высокоразвитой экономикой, прочными демократическими традициями, богатой историй и культурой. Нарушилось представление о европейской интеграции как о непрерывном поступательном процессе, в котором органично сочетаются углубление и территориальное расширение. Встал вопрос о выгодах интеграции для каждой отдельной страны, о соотношении порождаемых ею благ и издержек.

Вместе с тем брекзит создаёт условия для того, чтобы руководящие органы Евросоюза и политические элиты государств-членов начали поиск новой повестки 
дня взамен той, которая была реализована и потому исчерпана после расширения ЕС на восток. Негативный исход британского референдума резко повысил актуальность и практическую значимость общественной дискуссии о будущем европейской интеграции.

С выбытием Великобритании ЕС утрачивает монополию на истину. В Европе возникает два конкурирующих режима, ни один из которых нельзя более представить маргинальным или устаревшим на том основании, что он недостаточно демократичен или не отвечает принципам свободного рынка. Именно конкуренция, взаимные взгляды через Ла-Манш могут вернуть нынешнюю Европу в естественное для неё состояние соревнования политических систем, которого она лишилась после распада СССР. Эта конкуренция может стать богатым источником новых идей, смыслов и практик в наше непростое время - когда социально-экономическая структура ЕС, как и большинства стран мира, нуждается в коренной перестройке. Возникают условия для того, чтобы ЕС трансформировал свой нынешний ценностный подход в более прагматичный, ориентированный на решение конкретных задач.

\section{Список литературы}

Ананьева Е.В. (2018). Непредсказуемый брекзит. Научно-аналитический вестник ИЕ РАН, № 4, с. 99-105.

Андреева Т.Н. (2016). Великобритания. В кн.: Арбатова Н.К., Кокеев А.М. (ред.) Европейский союз на перепутье: нерешенные проблемы и новые вызовы (политические аспекты). ИМЭМО РАН, с 115-136.

Бабынина Л.О. (2019а). Брекзит: соглашение подписано, проблемы остаются. Европейский союз: факты и комментарии, № 94, с. 87-93.

Бабынина Л.О. (2019b). Влияние брекзита на фракционную структуру Европейского парламента. Современная Европа, № 5, с. 68-77.

Бабынина Л.О. (2019c). “Евросоюз: вызов брекзита”, в кн.: Громыко Ал.А., Фёдоров В.П. (ред.) Европа между трёх океанов. Нестор-История, Москва, Россия, 2019, с. 71-90.

Байков А.А. (2012). Сравнительная интеграция. Практика и модели интеграции в зарубежной Европе и Тихоокеанской Азии. Аспект Пресс, Москва, Россия, 256 с.

Байков А.А., Дымова Л.А. (2017). Выход Великобритании из ЕС и устойчивость европейской региональной структуры. Современная Европа, № 3, с. 37-46.

Буторина О.В. (2011). Европа без Евросоюза. Россия в глобальной политике, Том 9, № 6, с. 179-193.

Буторина О.В. (2013). Европейский союз после кризиса: упадок или возрождение? Вестник МГИМО Университета, № 4 (31), с. 71-81.

Буторина О.В. (2020). Экономическая история евро. Весь Мир, Москва, Россия, 576 с.

Вершинин А.А. (2017). Французская общественно-политическая мысль о кризисе современной евроинтеграции. Контуры глобальных трансформачий: политика, экономика, право. Том 10, № 1, с. 69-86.

Громыко Ал.А. (2017). Европейские исследования: дилеммы универсальности и уникальности (к 60-летию региональной интеграции). Современная Европа, № 2, с. 6-17.

Зидентоп, Ларри (2001). Демократия в Европе. Перевод с английского под ред. В.Л. Иноземцева. Логос, Москва, Россия, 360 с.

Кавешников Н.Ю. (2016). Некоторые последствия Brexit для развития Европейского союза. Вестник МГИМО Университета, № 6 (51), с. 24-30.

Кавешников Н.Ю. (2018а). Великобритания и Европейский союз: долгая история развода. Статья 1. Европейский вопрос. Современная Европа, № 5, с. 5-16.

Кавешников Н.Ю. (2018b). Великобритания и Европейский союз: долгая история развода. Статья 2. Сложный партнёр. Современная Европа, № 6, с. 18-29.

Хесин Е.С. (2020). Экономика Европейского союза: итоги посткризисного десятилетия. Мировая экономика и международные отночения, № 1, с. 73-81.

Худолей К.К., Ерёмина Н.В. (2017). Брекзит: новый “старый” выбор Великобритании, Совреленная Европа, № 3, с. 28-36.

Юд А.П. (2017). После Брекзита: десять тезисов о настоящем и будущем Европы, Актуальные проблемы Европь, № 1, с. 155-165. 


\section{References}

Anan'eva E.V. (2018). Nepredskazuemyj brekzit. Nauchno-analiticheskij vestnik IE RAN, no. 4, pp. 99-105.

Andreeva T.N. (2016). Velikobritanija, in Arbatova N.K., Kokeev A.M. (Eds.) Evropejskij sojuz na pereput'e: nereshennye problemy i novye vyzovy (politicheskie aspekty). IMEMO RAN, pp. 115-136.

Babynina L.O. (2019a). Brekzit: soglashenie podpisano, problemy ostajutsja. Evropejskij sojuz: fakty $i$ kommentarii, no. 94, pp. 87-93.

Babynina L.O. (2019b). Vlijanie brekzita na frakcionnuju strukturu Evropejskogo parlamenta. Sovremennaja Evropa, no. 5, pp. 68-77.

Babynina L.O. (2019c). „Evrosojuz: vyzov brekzita“, in Gromyko Al.A., Fjodorov V.P. (Eds.) Evropa mezhdu trjoh okeanov. Nestor-Istorija, Moscow, Russia, 2019, pp. 71-90.

Bajkov A.A. (2012). Sravnitel'naja integracija. Praktika i modeli integracii v zarubezhnoj Evrope $i$ Tihookeanskoj Azii. Aspekt Press, Moscow, Russia, 256 p.

Bajkov A.A., Dymova L.A. (2017). Vyhod Velikobritanii iz ES i ustojchivost' evropejskoj regional'noj struktury. Sovremennaja Evropa, no. 3, pp. 37-46.

Bickerton, Christopher (2019) 'Parliamentary', 'popular' and 'pooled': conflicts of sovereignty in the United Kingdom's exit from the European Union, Journal of European Integration, Vol. 41, Issue 7, pp. 887-902.

Brandt W. (1969). Statement by M. Willy Brandt, Chancellor of the Federal Republic of Germany (translation). In: Meeting of the heads of state or government, The Hague, 2 December 1969. Available at: http://aei.pitt.edu/1451/1/hague_1969.pdf

Butorina O.V. (2011). A Europe without the European Union? Russia in Global Affairs, Vol. 9, no. 4, pp. 181-196.

Butorina O.V. (2013). Evropejskij sojuz posle krizisa: upadok ili vozrozhdenie? Vestnik MGIMO Universiteta, no. 4 (31), pp. 71-81.

Butorina O.V. (2020). Jekonomicheskaja istorija evro. Ves' Mir, Moscow, Russia, 576 p.

de Guindos, Luis (2020). Europe's role in the global financial system. Speech by Luis de Guindos, VicePresident of the ECB, at the SUERF/De Nederlandsche Bank Conference "Forging a new future between the UK and the EU", Amsterdam, 8 January.

European Commission (1969). Memorandum from the Commission to the Conference (19 November 1969). In: Meeting of the heads of state or government, The Hague, 2 December 1969. Available at: http://aei.pitt.edu/1451/1/hague_1969.pdf

European Commission (2012). Special Eurobarometer 386 Europeans and their Languages, Summary, June 2012.

European Commission (2017). White Paper on the Future of Europe. Reflections and scenarios for the EU27 by 2025, 1 March.

European Commission (2020a). Shaping Europe's Digital Future.

European Commission (2020b). Temporary Framework for State aid measures to support the economy in the current COVID-19 outbreak. Communication from the Commission. Brussels, 19.3.2020 C(2020) 1863 final.

European Commission (2020c). Communication from the Commission to the Council on the activation of the general escape clause of the Stability and Growth Pact. Brussels, 20.3.2020 COM(2020) 123 final

European Communities (1969). The "Summit Conference" The Hague, Statements made by the Heads of State or Government on 2 December 1969, Reproduced from the Bulletin of the European Communities, No. 2, 1970. In: Meeting of the heads of state or government, The Hague, 2 December 1969. Available at: http://aei.pitt.edu/1451/1/hague_1969.pdf

Felbermayr, Gabriel (2019). Brexit: A Hard-but-Smart Strategy and Its Consequences, Intereconomics, Vol. 54, No 3, pp. 178-183.

Gromyko Al.A. (2017). Evropejskie issledovanija: dilemmy universal'nosti i unikal'nosti (k 60-letiju regional'noj integracii). Sovremennaja Evropa, no. 2, pp. 6-17.

Hesin E.S. (2020). Jekonomika Evropejskogo sojuza: itogi postkrizisnogo desjatiletija. Mirovaja jekonomika i mezhdunarodnye otnoshenija, no. 1, pp. 73-81.

Hude, Henri Paul (2017). Après le Brexit: dix thèses sur le présent et l'avenir de l'Europe, Aktual'nye problemy Evropy, no. 1, pp. 155-165.

Hudolej K.K., Erjomina N.V. (2017). Brekzit: novyj "staryj” vybor Velikobritanii, Sovremennaja Evropa, no. 3, pp. 28-36.

Kaveshnikov N.Ju. (2016). Nekotorye posledstvija Brexit dlja razvitija Evropejskogo sojuza. Vestnik MGIMO Universiteta, no. 6 (51), pp. 24-30. 
Kaveshnikov N.Ju. (2018a). Velikobritanija i Evropejskij sojuz: dolgaja istorija razvoda. Stat'ja 1. Evropejskij vopros. Sovremennaja Evropa, no. 5, pp. 5-16.

Kaveshnikov N.Ju. (2018b). Velikobritanija i Evropejskij sojuz: dolgaja istorija razvoda. Stat'ja 2. Slozhnyj partner. Sovremennaja Evropa, no. 6, pp. 18-29.

Leruth, Benjamin, Gänzle, Stefan and Trondal, Jarle (2019a). Exploring Differentiated Disintegration in a Post-Brexit European Union. Journal of Common Market Studies, Vol. 57, Issue 5, pp. 1013-1030.

Leruth, Benjamin, Gänzle, Stefan and Trondal, Jarle (2019b). Differentiated Integration and Disintegration in the EU after Brexit: Risks versus Opportunities. Journal of Common Market Studies, Vol. 57, Issue 6, pp. 1383-1393.

Murray, Philomena and Brainson, Alex (2019). Rethinking Britain's Role in a Differentiated Europe after Brexit: A Comparative Regionalism Perspective. Journal of Common Market Studies, Vol. 57, Issue 6, pp. 1431-1442.

Pelkmans, Jacques (2019). Just a little Brexit?: 'Alternative (customs) arrangements' and the Withdrawal Agreement, CEPS Policy Insights, No 2019-13, September 19.

Pompidou G. (1969). Statement by M. Georges Pompidou, President of France (translation). In: Meeting of the heads of state or government, The Hague, 2 December 1969. Available at: http://aei.pitt.edu/1451/1/hague_1969.pdf

Rodríguez Suárez, P. M. (20120). El Brexit y el futuro de Europa. OASIS, 31, pp. 147-166.

Siedentop, Larry (2000). Democracy in Europe. Allen Lane, The Penguin Press.

Tusk, Donald (2017). United we stand, divided we fall. Letter by President Donald Tusk to the 27 EU heads of state or government on the future of the EU before the Malta summit, 31 January. https://www.consilium.europa.eu/en/press/press-releases/2017/01/31/tusk-letter-future-europe/

Van Rompuy (2014). Invitation letter by President Herman Van Rompuy to the Special Meeting of the European Council. EUCO 148/14 PRESSE 403 PR PCE 132 Brussels, 15 July 2014.

Vershinin A.A. (2017). Francuzskaja obshhestvenno-politicheskaja mysl' o krizise sovremennoj evrointegracii. Kontury global'nyh transformacij: politika, jekonomika, pravo. Vol. 10, no. 1, pp. 69-86.

Von der Leyen, Ursula (2019). A Union that strives for more. My agenda for Europe by candidate for President of the European Commission. Political guidelines for the next European Commission 2019=2024.

\section{The Shrinking of the European Union and its Integration Capability}

Author: Butorina O., Corresponding Member RAS, Doctor of Economic Sciences, Professor, Deputy Director for Research, Institute of Europe, Russian Academy of Sciences. Address: 11-3, Mokhovaya str., Moscow, Russia, 125009. E-mail: butorina@ieras.ru

Abstract. The United Kingdom, a country with 67 million people and the world's fifth largest economy, formally withdrew from the European Union on 31 January 2020. Apart from the loss of Greenland in 1985, the Union has been expanding for decades; now for the first time in its history it is shrinking. The existing literature on Brexit focuses mainly on Great Britain and, to a lesser extent, the European Union. The latter material predominantly addresses institutional issues. There have been a number of scholarly assessments of differentiated integration and disintegration in the EU after Brexit, as well as of the changing nexus between intergovernmental and supranational instruments. This article contributes to a broader debate on the subsequent evolution of European integration with an emphasis on its intrinsic driving forces, rather than on forms and methods. Our analysis shows that, although the European Union will suffer significant economic, political and semantic losses, Brexit may also galvanize the integration process. It may create the necessary premises for the emergence of two competing democratic regimes in Europe. This new situation draws a line under the 30-year period (since the fall of the Berlin Wall) of the EU's ideological and institutional dominance as an uncontested model of European development. Potential political and normative rivalry with the United Kingdom may be extremely stimulating for the European Union, pushing it to reassess its attitudes, reject dogma and develop a new integration ideology that would respond to the challenges of unchecked economic globalization and set aside outdated patterns of the bipolar world order.

Keywords: The European Union, the United Kingdom, Brexit, regional integration, disintegration.

DOI: http://dx.doi.org/10.15211/soveurope220202032 